\title{
Labyrinthe
}

15 | 2003

Territoires : questions d'images

\section{Questions de ville et de projet}

Colloque organisé par le laboratoire "Théorie des mutations urbaines" à

l'Institut français d'urbanisme, les 13 et 14 décembre 2001

\section{Maria Basile}

\section{Q OpenEdition}

12 Journals

Édition électronique

URL : http://journals.openedition.org/labyrinthe/487

DOI : $10.4000 /$ labyrinthe.487

ISSN : 1950-6031

Éditeur

Hermann

Édition imprimée

Date de publication : 1 juin 2003

Pagination : 117-122

Référence électronique

Maria Basile, "Questions de ville et de projet », Labyrinthe [En ligne], 15 | 2003, mis en ligne le 24 mars 2005, consulté le 20 avril 2019. URL : http://journals.openedition.org/labyrinthe/487 ; DOI : 10.4000/ labyrinthe.487

Ce document a été généré automatiquement le 20 avril 2019.

Propriété intellectuelle 


\section{Questions de ville et de projet}

Colloque organisé par le laboratoire "Théorie des mutations urbaines" à

l'Institut français d'urbanisme, les 13 et 14 décembre 2001

Maria Basile 